\title{
Chiroptical Properties of (+)-Corycavine and Corycavamine
}

\author{
Miyoko Kamigauchi*, Yuko Noda, Kinuko Iwasa, and Narao Takao \\ Kobe Women's College of Pharmacy, Motoyama-kitamachi, Higashinada-ku, Kobe 658, Japan
}

Wolfgang Wiegrebe

Faculty of Chemistry and Pharmacy, Regensburg University, P.O. Box 397, D-8400 Regensburg, Germany

Received August 1, 1989

The resolution of racemic corycavine via its (t)-10-camphorsulfonate, the equivalency of $(+)$-corycavine and corycavamine, as well as the racemization of (+)-corycavine are described. $13 R$-Configuration is assigned to (+)-corycavine, based on $\mathrm{CD}$ data.
Chiroptische Eigenschaften von (+)-Corycavin und Corycavamin

Die Enantiomerentrennung von razemischem Corycavin über das (+)-10Kampfersulfonat, die Identität von (t)-Corycavin mit Corycavamin und die Razemisierung von (+)-Corycavin werden beschrieben. Aufgrund von CDMessungen wird (+)-Corycavin 13R-Konfiguration zugeordnet.
Corycavine (1) ${ }^{1)}$ and corycavamine ${ }^{2)}$ (Scheme 1) were isolated from Corydalis cava (tuberosa), papaveraceae, in 1894 and 1902, respectively. The structure of these alkaloids was proposed by von Bruchhausen ${ }^{3)}$ in 1925 as 1, indicating that these compounds are protopine type alkaloids ${ }^{4)}$. V. Bruchhausen ${ }^{3)}$ termed the optically inactive form, m.p. $217-218^{\circ} \mathrm{C}$ corycavine (1), while the optically active form with a specific rotation of $+166.6^{\circ}$ (m.p. $148-149^{\circ} \mathrm{C}$ ) is termed corycavamine (2).

Crystallographic data presented in our previous paper ${ }^{5)}$ demonstrated that corycavine (1) exactly fits the "racemic form". Several reports ${ }^{6)}$ concerning the isolation of $( \pm)$-corycavine (1) have been described. However, since $\mathrm{Ga}$ damer's description, we have not seen lit. regarding the isolation of corycavamine (2). In general, it seems relatively unique for naturally occurring alkaloids bearing an asymmetric $\mathrm{C}$-atom to be isolated as a racemate only. Further, the lit. cited above ${ }^{3)}$ also described racemization occurring from heating with acetic anhydride at above $180^{\circ} \mathrm{C}$. One can, therefore, presume that corycavamine (2) converts to ( $( \pm)-$ corycavine (1) relatively easily through usual isolation treatment.

In biosynthesis, protopine type alkaloids are key intermediate to benzo[c]phenanthridine type (sanguinarine, etc.), and to hydrobenzo[c]phenanthridine type (corynoline and chelidonine, etc.), having pharmacological significance ${ }^{7)}$. The relationship between the absolute configurations of both types tells us what kind of enzymatic reaction mechanism takes place at the ring reconstitution stage. Thus, it seemed important to investigate further the absolute configuration and chiroptical properties of protopine type alkaloids.

The present paper deals with the optical resolution of $( \pm)$ corycavine (1), and the measurement of racemization of $(+)$ corycavine (2), by the circular dichroism (CD) method and by ${ }^{1} \mathrm{H}-\mathrm{NMR}$ spectroscopy, as well as a consideration of the absolute configuration of ( + )-corycavine (2) and its derivatives by $C D$.

\section{Optical Resolution of $\mathbf{1}$ and Identification with Corycavamine}

The resolution of racemic corycavine (1) is important for comparison with the optically active corycavamine (2), for which data are available ${ }^{8)}$.

( \pm )-Corycavine (1) was isolated from Corydalis incisa, papaveraceae, and optical resolution of 1 with (+)-10-camphorsulfonic acid was carried out by fractional crystallization of the diastereomeric salts. At first, transparent plates m.p. $282-287^{\circ} \mathrm{C}$ separated which were transformed to the optically active (-)-corycavine (3) as free base, colorless needles, m.p. $145-148^{\circ} \mathrm{C},[\alpha]_{D}-170^{\circ}$. The optical isomer was obtained in the same manner from the mother liquor after successive recrystallization. The diastereomeric salt, transparent needles, m.p. $275-276^{\circ} \mathrm{C}$, gave the optically active enantiomeric base ( + )-corycavine (2), colorless needles, m.p. $145-146^{\circ} \mathrm{C},[\alpha]_{D}+172^{\circ} .100 \%$ optical purities of each $(+)$ - and (-)-corycavine ( 2 and 3 ) were confirmed as follows: 1) The numerical values of the melting points and the

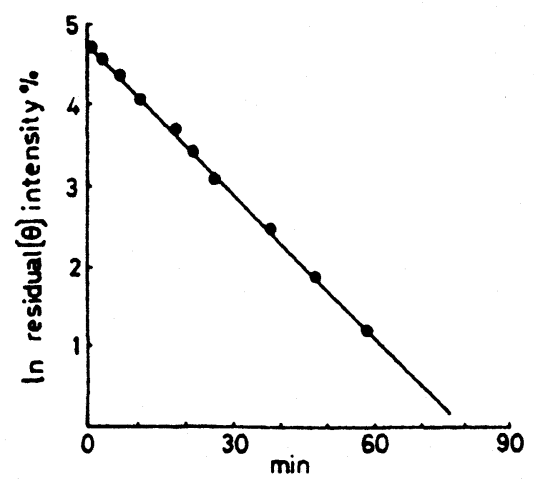

Fig. 1 The rate of racemization of 3 . Residual $[\theta]$ intensity $\%=[\theta]$-value at $X$ min after/initial $[\theta]$-value $X 100$. 
specific optical rotation of 2 and 3 were not altered by recrystallization. 2) The IR-spectrum of 2 in $\mathrm{KBr}$ substantially agreed with the spectrum of 3 , but did not agree with the spectrum of 1 . All three spectra agreed in solution. 3) The CD-spectra of 2 and 3 are also equal in intensity though opposite in sign. Melting point, crystal form, specific optical rotation, etc. of 2 prepared in this way agreed very closely with those of corycavamine described by Gadamer). Consequently, one can conclude that corycavamine is identical with (+)-corycavine (2) with $100 \%$ optical purity.

\section{Measurements of Racemization of 2 and 3}

The chiral center C-13 in 2 is located in the $\alpha$-position of the keto group and in benzyl-position. Consequently, racemization of 2 is believed to be relatively easy. In order to study this racemization, the rate was investigated under alkaline conditions generally used for isolation of alkaloids from various plants.

The time-course of CD-band intensities at $286 \mathrm{~nm}$ of 3 was measured in ethanolic $\mathrm{NaOH}$ at $20^{\circ} \mathrm{C}$. The rate of remaining optical activity of 3 was calculated by use of the value [ $\theta]$ at $286 \mathrm{~nm}$, and the slope for the data was determined by the least-squares method (Fig. 1). The rate of racemization of 3 was $5.96 \times 10^{-2} \mathrm{~min}^{-1}$ and the half-life period was $11.6 \mathrm{~min}$. The similarity of this value to that of (-)-1,2-diphenyl-propan-1-one $e^{9)}$ suggests that the racemization rate of 3 is due to its having in part the same structure.

From the ${ }^{1} \mathrm{H}-\mathrm{NMR}$ results, furthermore, we elicited information about the racemization of 2 . All proton resonances

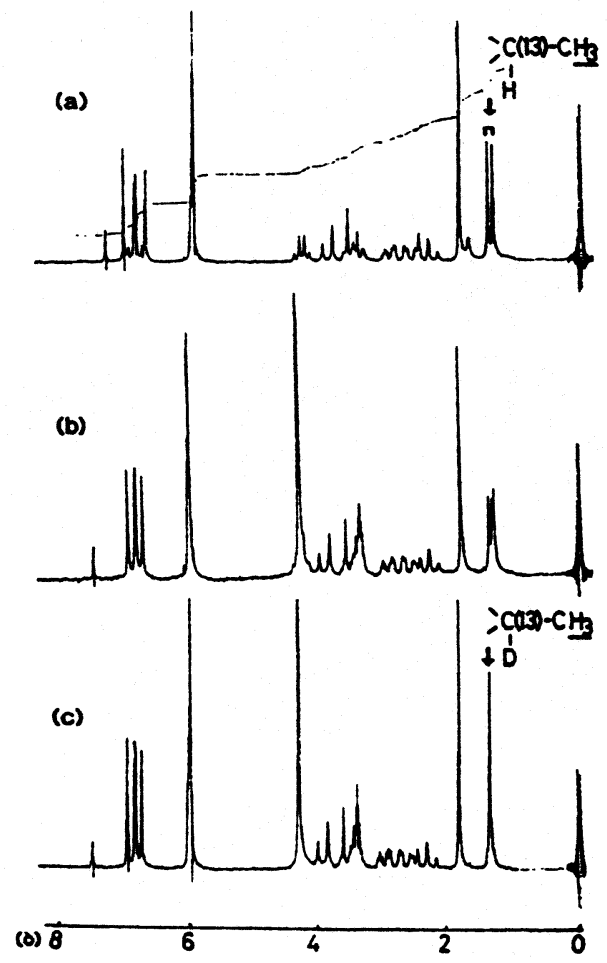

Fig. $2{ }^{1} \mathrm{H}$-NMR spectra of 2 in $\mathrm{CDCl}_{3}$ at $27^{\circ} \mathrm{C}$. (a) Spectrum of 2 . (b) Addition of $\mathrm{NaOD}$ in $\mathrm{CD}_{3} \mathrm{OD}$ and delay of several min. (c) Addition of $\mathrm{NaOD}$ in $\mathrm{CD}_{3} \mathrm{OD}$ and delay of $3 \mathrm{~h}$. in $\mathrm{CDCl}_{3}$ have been assigned ${ }^{5}$. The spectrum (Fig. 2a) displayed the methyl protons $\left(\mathrm{C}-13 \mathrm{H}-\mathrm{CH}_{3}\right)$ as a doublet with $\mathrm{J}$ $=7 \mathrm{~Hz}$ at $\delta=1.36$. By addition of $\mathrm{NaOD}$ in $\mathrm{CD}_{3} \mathrm{OD}$ this doublet collapsed to a singlet at $\delta=1.36$ (spectrum b); after $3 \mathrm{~h}$, the spectrum c showed only the deuterated species. This phenomenon is due to the disappearance of the proton coupling (C-13D- $\left.\mathrm{CH}_{3}\right)$. The ${ }^{1} \mathrm{H}-\mathrm{NMR}$ spectra indicate that the asymmetric carbon atom $\mathrm{C}-13$ of 2 bears a readily ionizable hydrogen atom which exchanges easily $H$ against $D$.

These results show that optically active 13-substituted protopine type alkaloids are rapidly converted into racemates under mild alkaline conditions. This suggests that, if isolation from plants is meticulously carried out, the optically active form in the corycavine/corycavamine fraction may be obtained. The isolation of naturally occurring 2 from Corydalis incisa and Corydalis cava was studied again. The examination showed that 2 comprises $60 \%$ in the 1 and 2 fraction from Corydalis incisa and 14\% from $C$. cava plants.

\section{Relationship between $C D$-Spectra and the Absolute Configuration of 2 and its Derivatives}

The CD-spectrum of 2 is of interest in connection with the absolute configuration of the asymmetric $\mathrm{C}-13$ atom. While the ORD- and CD-spectral investigation of protoberberine type alkaloids has been reported in several papers ${ }^{10}$, no study has been reported on the chiroptical discussion of protopine type. Earlier work ${ }^{5}$ ) had shown that for 1 , in spite of a ten-membered ring system with one rigid conformation in solution, direct use of the empirically CD-spectral rule derived from protoberberine type compounds for corycavine was problematic. Consequently, 2 was converted into a protoberberine by reductive ring closure, and the CD-spectrum of that derivative was also investigated.

The protopine skeleton of ( + )-corycavine was transformed to a protoberberine skeleton as follows (Scheme 1): Reduction of 2 with $\mathrm{LiAlH}_{4}$ gave the optically active (+)-dihydro-

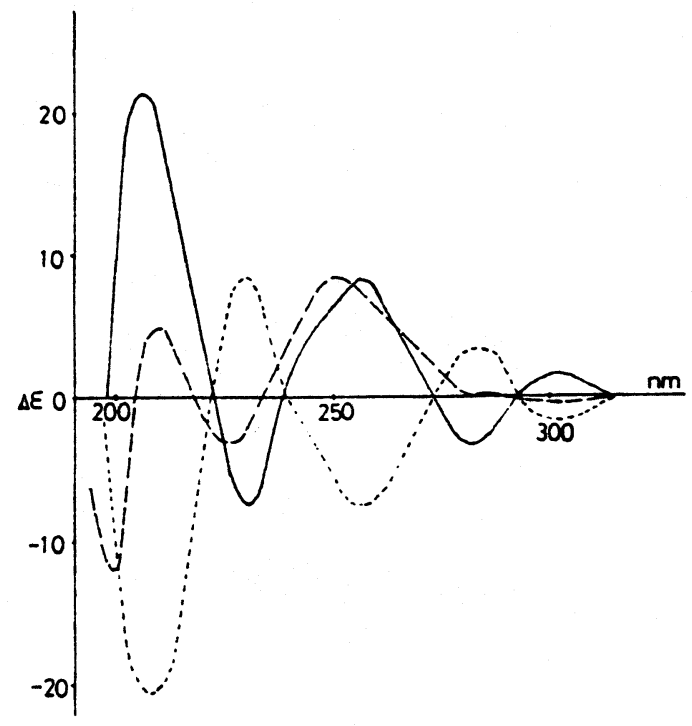

Fig. $3 \mathrm{CD}$ spectra of 2,3, and 4 in $\mathrm{MeOH}$. - 2 --- $3--4$. 
corycavine (4). 4 was treated with aqu. $\mathrm{HCl}$, followed by addition of $\mathrm{KI}$. The ring closure product was identical with (+)-meso-terahydrocorysamine $N$-methiodide (5). aromatic chromophore. Accordingly, a remarkable reduction in the magnitude of the $290 \mathrm{~nm}$ absorption for 4, compared with 2 and 3, is attributable to the disappearance of

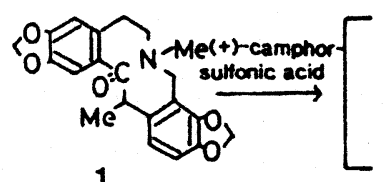

Scheme 1

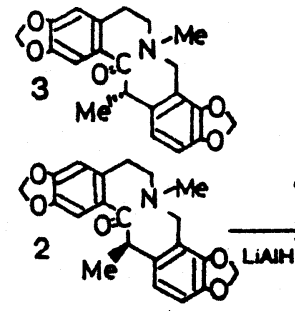

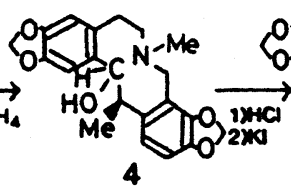

4

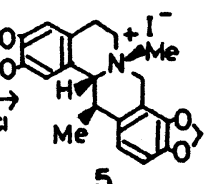

5
The CD-spectra of 2, 3, and 4 are shown in Fig. 3. The curve for 2 shows from the side of the long wave length positive and negative maxima in $\alpha$-band (at around 290 $\mathrm{nm})$, in $p$-band $(\mathrm{at}=240 \mathrm{~nm}$ ) and in $\beta$-band (at $\approx 200 \mathrm{~nm}$ ). The curve of 3 is the mirror-image of 2 . A striking characteristic of the spectra of $\mathbf{2}$ and 3 is the high amplitude of the

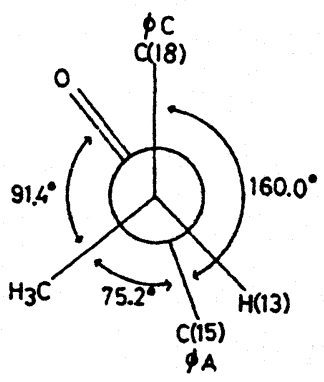

Fig. 4 Newman projection $(C(13) \rightarrow C(14))$ of 1 .

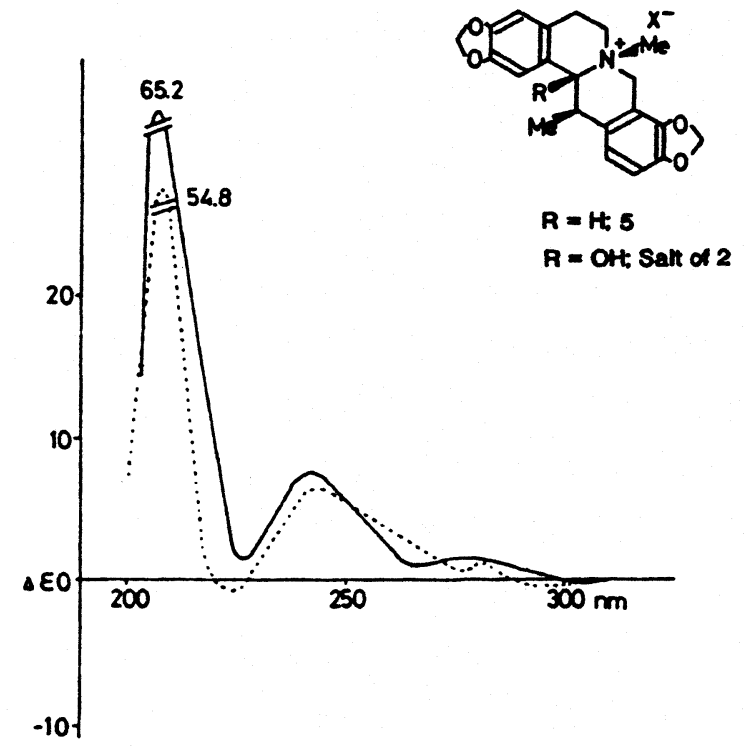

Fig. 5 CD spectra of 5 and salt of 2 in MeOH. - 5 -.- Trifluoroacetate of 2.

$290 \mathrm{~nm}$ Cotton effects. As indicated in Fig. 4, which shows the Newman projection (C-13 $\rightarrow$ C-14) of 1 as revealed by $\mathrm{X}$-ray analysis ${ }^{5}$, they may be influenced by the $n-\pi^{*}$ transition of the carbonyl group upon the $\pi-\pi^{*}$ transition of the the $\mathrm{C}=\mathrm{O}$ group, now converted into the $\mathrm{OH}$-group. In addition, the remarkable reduction in the magnitude of the Cotton effect near $200 \mathrm{~nm}$ in 4 may be attributed to the conformational change of ring $B$, due to the flexibility of this ten-membered ring.

It is known ${ }^{11)}$ that protonation of protopine type alkaloids leads to a quaternary form similar to the quaternary methiodides of protoberberine type alkaloids. The preferred conformation of the salt of $\mathbf{2}$ may be the cis-quinolizidine system, in order to avoid the steric hindrance between the C13-methyl group and the two protons at C-1 and C-12. This is also confirmed by the NMR study ${ }^{12)}$. The CD-spectra of the TFA salt of 2 and 5 are shown in Fig. 5. Each compound has two asymmetric carbons and an asymmetric $\mathrm{N}$-atom and they differ only in the substituent at C-13a. Both curves have intrinsically similar $C D$ properties. From a consideration of the whole spectral pattern and from a comparison of the $\mathrm{CD}$ data with that of other protoberberine type alkaloids ${ }^{10)}$, it seems most reasonable to conclude that the absolute configuration of the salt of 2 must be assigned as $7 \mathrm{~N}(R), 13(R)$, and $13 \mathrm{a}(S)$.

Therefore, the absolute configuration of 2 -base must be assigned as $13(R)$.

The support of this work by a research grant from the Alexander von Humboldt-Stiftung in Germany is gratefully acknowledged. The authors wish to thank Dr. T. Iwata (Shionogi Research Laboratory, Shionogi and Co. Ltd.), for CD-spectral data. We also wish to thank Prof. Dr. Franz and Prof. Dr. Bresinsky, Botanischer Garten der Universităt Regensburg, for providing us plant material of Corydalis cava.

\section{Experimental Part}

\section{General Remarks}

Melting points: Kofler hot stage apparatus, uncorrected.- IR spectra: EPI-C2 (Hitachi), nujol, $\mathrm{KBr}$ pellets, $\mathrm{CHCl}_{3}$ solution.- Mass spectra: JEOL-DIS.- ' H-NMR spectra: Varian-XL-200 (200 MHz, FT-mode), TMS as internal standard. Coupling constants $\mathrm{J}$ in Hz.- Optical rotations: DIP-SL (JASCO) polarimeter.- CD spectra: ORD/UV-5 and CD-J-500C (JASCO), data were measured at ca. $3 \times 10^{-4} \mathrm{~mol} / \mathrm{h}$ at $20^{\circ} \mathrm{C}$ in cells of $0.1-5 \mathrm{~mm}$ path lengths.

\section{Optical resolution of ( \pm )-corycavine (1)}

To a solution of $1(157 \mathrm{mg})$ in methanol was added a solution of (+)camphorsulfonic acid $(100 \mathrm{mg})$ in methanol. After removal of the solvent. the remaining residue gave the ( \pm )-corycavine (+)-camphorsulfonatae, m.p. 
$273-275^{\circ} \mathrm{C}$. The salt was recrystallized from a mixed solvent (methanol, acetone, ether) three times for $12 \mathrm{~h}$ at room temp. to give (-)-corycavine (+)-camphorsulfonate $(40 \mathrm{mg})$ as colorless plates, m.p. $282-287^{\circ} \mathrm{C}$. The crystals were dissolved in $\mathrm{H}_{2} \mathrm{O}(50 \mathrm{ml})$. The aqueous solution was made faintly alkaline to litmus with $5 \% \mathrm{NH}_{3} / \mathrm{H}_{2} \mathrm{O}$ and extracted rapidly with ether $(2 \times 20 \mathrm{ml})$. The org. phase was washed with saturated $\mathrm{NaCl}$ solution $\left(2 \times 20 \mathrm{ml}\right.$ ), dried with $\mathrm{Na}_{2} \mathrm{SO}_{4}$ and evaporated in vacuo. The residue was crystallized from ether/petroleum ether to give $24 \mathrm{mg}$ of (-)-corycavine: transparent needles, m.p. $145-146^{\circ} \mathrm{C}$. $[\alpha]_{\mathrm{D}}^{25}-170.0^{\circ}\left(\mathrm{c}=1.3, \mathrm{CHCl}_{3}\right)$.$\mathrm{C}_{21} \mathrm{H}_{21} \mathrm{O}_{5} \mathrm{~N}(367.1) \mathrm{Calcd}$. C $68.6 \mathrm{H} 5.76 \mathrm{~N} 3.8$ Found C 68.5 H $5.84 \mathrm{~N}$ 4.0.- IR: $v \max$ (Nujol) $1665 \mathrm{~cm}^{-1}$.- EIMS: $367\left(\mathrm{M}^{+}: 4\right), 281$ (4), 204 (8), 162 (100). - CD (MeOH) $\Delta \varepsilon(\mathrm{nm}):+0.08$ (320), -1.74 (301), +3.55 (281.5), -0.27 (257), +8.70 (230), -21.09 (207). ${ }^{1} \mathrm{H}-\mathrm{NMR}\left(\mathrm{CDCl}_{3}\right): \delta(\mathrm{ppm})=7.02$ (1H, s, H-1), $6.87(1 \mathrm{H}, \mathrm{d}, \mathrm{J}=8.5 \mathrm{~Hz}, \mathrm{H}-12), 6.81(1 \mathrm{H}, \mathrm{d}, \mathrm{J}=8.5 \mathrm{~Hz}, \mathrm{H}-11)$, $6.67(1 \mathrm{H}, \mathrm{s}, \mathrm{H}-4), 6.01,5.98\left(2 \mathrm{H}, 2 \mathrm{~d}, \mathrm{~J}=1.0 \mathrm{~Hz}, \mathrm{O}-\mathrm{CH}_{2}-\mathrm{O}\right), 5.96(2 \mathrm{H}, \mathrm{s}$, O- $\mathrm{CH}_{2}-\mathrm{O}$ ), $4.26(1 \mathrm{H}, \mathrm{q}, \mathrm{J}=7.3 \mathrm{~Hz}, \mathrm{H}-13$ ), 3.85, 3.50 (each $1 \mathrm{H}, \mathrm{d}, \mathrm{J}=14$ Hz, H-8), 3.45, 2.56 (each 1H, m, H-5), 2.89, 2.30 (each 1H, m, H-6), 1.83 $\left(3 \mathrm{H}, \mathrm{s}, \mathrm{N}-\mathrm{CH}_{3}\right), 1.36\left(3 \mathrm{H}, \mathrm{d}, \mathrm{J}=7.3 \mathrm{~Hz}, \mathrm{C}-\mathrm{CH}_{3}\right)$.

The mother liquor was evaporated, and the residue gave ( + -corycavine (t)-10-camphorsulfonate as colorless needles (25 mg, m.p. $274-276^{\circ} \mathrm{C}$ ) after 3 successive recrystallizations from a mixed solvent (MeOH, acetone, ether). The salt was treated according to the above procedure for (-)-corycavine salt, to afford $14 \mathrm{mg}$ of (+)-corycavine with ether/petroleum ether, transparent needles, m.p. $145-146^{\circ} \mathrm{C} .-[\alpha]_{\mathrm{D}}^{2 S}+172.0^{\circ}\left(\mathrm{c}=1.0, \mathrm{CHCl}_{3}\right)$.$\mathrm{C}_{21} \mathrm{H}_{21} \mathrm{O}_{5} \mathrm{~N}$ (367.1) Calcd. C $68.6 \mathrm{H} 5.76 \mathrm{~N} 3.8$ Found C $68.5 \mathrm{H} 5.81 \mathrm{~N}$ 4.0.- IR: v $\max$ (Nujol) $1665 \mathrm{~cm}^{-1}$.- EIMS: $367\left(\mathrm{M}^{+}\right), 281,204,162 .-\mathrm{CD}$ (MeOH) $\Delta \varepsilon$ (nm): $-0.10(320),+1.78$ (300), $-3.70(281),+8.28$ (256), -7.86 (230), +21.21 (207).- CD ( $\left.\mathrm{MeOH}+\mathrm{CF}_{3} \mathrm{COOH}\right):-0.31$ (297.5), +0.93 (280), +6.64 (243), -1.10 (224), +54.93 (209), - 11.88 (197).

\section{Isolation of 1 and 2 from Corydalis cava and C. incisa}

The plants $(70 \mathrm{~g}$, dry weight) were soaked in $\mathrm{MeOH}(3 \times 500 \mathrm{ml})$ at room temp. for $24 \mathrm{~h}$, then the mixture was filtered. The extracts were combined and evaporated in vacuo. The residue was extracted with tartaric acid $(3 \%, 300 \mathrm{ml})$. This acid layer was washed with ether $(2 \times 150 \mathrm{ml})$ and its $\mathrm{pH}$ adjusted to 7.5 ( $5 \%$ aqueous $\mathrm{NH}_{3}$ ). The alkaline solution was immediately extracted with ether $(2 \times 200 \mathrm{ml})$ and the combined ether layer was dried $\left(\mathrm{K}_{2} \mathrm{CO}_{3}\right)$ and evaporated to give an oil. The oil was chromatographed by prep. TLC $\left(\mathrm{SiO}_{2}\right.$; benzene:ether = 1:1; elution $\left.\mathrm{CHCl}_{3}\right)$ to yield the mixture of $1+2(R f=0.26)$ as an oil. 1/2-Fraction from $C$. cava: $2.8 \mathrm{mg}$, $[\alpha]_{D}^{25}+24.0^{\circ}\left(\mathrm{c}=0.2, \mathrm{CHCl}_{3}\right) .1 / 2$-Fraction from $C$. incisa: $5.9 \mathrm{mg},[\alpha]_{D}^{25}$ $+102.5^{\circ}\left(\mathrm{c}=0.5, \mathrm{CHCl}_{3}\right)$.

\section{Preparation of (+)-Dihydrocorycavine (4)}

To $2(20 \mathrm{mg})$ in absol. benzene, $\mathrm{LiAlH}_{4}(10 \mathrm{mg})$ in absol. $\mathrm{Et}_{2} \mathrm{O}$ was added slowly drop by drop with stirring under $\mathrm{N}_{2}$ at room temp. After keeping for $2 \mathrm{~h}, \mathrm{H}_{2} \mathrm{SO}_{4}(10 \%, 10 \mathrm{ml})$ and $\mathrm{NaOH}(10 \%, 60 \mathrm{ml})$ were successively added to the reaction mixture. The resulting solution was extracted with ether $(2 \times 50 \mathrm{ml})$. The ether layer was washed with saturated $\mathrm{NaCl}$-solution, dried $\left(\mathrm{K}_{2} \mathrm{CO}_{3}\right)$, and evaporated to give (+)-4 $(6.7 \mathrm{mg})$. Recrystallization from methanol gave colorless columns, m.p. $219-220^{\circ} \mathrm{C}$.$[\alpha]_{D}^{25}+43.0^{\circ}\left(\mathrm{c}=0.7, \mathrm{CHCl}_{3}\right)$.- IR: $\vee \max (\mathrm{KBr})=3420 ; 3100 \mathrm{~cm}^{-1}$.EIMS: $369\left(\mathrm{M}^{+}, 3\right), 206(16), 163$ (31), 162 (100).- $\mathrm{C}_{21} \mathrm{H}_{23} \mathrm{O}_{5} \mathrm{~N}$ (369.1)
Caled. C 68.3 H 6.28 N 3.8 Found C 68.2 H 6.27 N 3.8.- CD MeOH $\Delta \varepsilon$ $(\mathrm{nm}):-0.14$ (299), +0.39 (280), +9.02 (248), -3.27 (227), +4.90 (210). -12.09 (201). $\left(\mathrm{CH}_{3} \mathrm{CN}\right)-0.48(229),+0.47(282),+9.01(250),-4.07$ (230), +4.00 (211), -19.3 (202). - ${ }^{1} \mathrm{H}-\mathrm{NMR}\left(\mathrm{CDCl}_{3}\right.$ at $\left.60^{\circ} \mathrm{C}\right): \delta(\mathrm{ppm})=7.75(1 \mathrm{H}$. $\mathrm{m}, \mathrm{C}-13-\mathrm{OH}$ ), 6.92 (1H, d. J = 8.0 Hz, H-12), $6.78(1 \mathrm{H}, \mathrm{d} . \mathrm{J}=8.0 \mathrm{~Hz}$. $\mathrm{H}-11), 6.73$ (1H, s, H-1), 6.62 (1H, s. H-4), 5.93 (4H, s, $\left.2 \times 0-\mathrm{CH}_{2}-\mathrm{O}\right)$, $4.36(1 \mathrm{H}, \mathrm{m}, \mathrm{H}-14), 3.66(2 \mathrm{H}, \mathrm{dd}, \mathrm{J}=14.0$ and $18.0 \mathrm{~Hz}, \mathrm{H}-8), 3.56(1 \mathrm{H}, \mathrm{m}$, $\mathrm{H}-13), 3.02(4 \mathrm{H}, \mathrm{m}, \mathrm{H}-5$ and $\mathrm{H}-6), 2.35\left(3 \mathrm{H}, \mathrm{s}, \mathrm{N}-\mathrm{CH}_{3}\right), 1.34(3 \mathrm{H}, \mathrm{d}, \mathrm{J}=$ $\left.7.0 \mathrm{~Hz}, \mathrm{C}-\mathrm{CH}_{3}\right)$.

\section{4. (+)-Mesotetrahydrocorysamine $N$-methiodide (5)}

To (t)-4 (46 mg), $\mathrm{HCl}(20 \%, 0.5 \mathrm{ml})$ was added, and the mixture was heated on a water bath for $4 \mathrm{~h}$. After cooling, $\mathrm{H}_{2} \mathrm{O}(5 \mathrm{ml})$ was added. To the solution, a saturated solution of $\mathrm{KI}$ was added in drops until no more precipitation was observed. The precipitate was collected with filtration

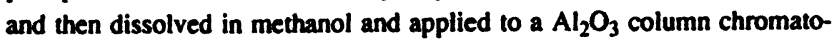
graphy (MeOH). Recrystallization from methanol afforded $13 \mathrm{mg}$ of $(+)-5$ as colorless prisms, m.p. $240-250^{\circ} \mathrm{C} .-[\alpha]^{25} \mathrm{D}+192^{\circ}(\mathrm{c}=0.8, \mathrm{MeOH})$.$\mathrm{C}_{21} \mathrm{H}_{22} \mathrm{O}_{4} \mathrm{NI}$ (479.3) Calcd. C $52.6 \mathrm{H} 4.63 \mathrm{~N} 2.9$ Found C $52.5 \mathrm{H} 4.58 \mathrm{~N}$ 2.9. CD MeOH $\Delta \varepsilon(\mathrm{nm}):-0.11(302),+1.21$ (283), +7.94 (242), +65.2 (209).

\section{References}

1 M. Freund and W. Josephi, Liebigs Ann. Chem. 277, 15 (1894).

2 J. Gadamer, Arch. Pharm. 240, 21 (1902); J. Gadamer and H. Ziegenbein, Arch. Pharm. 240, 83 (1902).

3 J. Gadamer and F. v. Bruchhausen, Arch. Pharm. 260, 97 (1922); F. v. Bruchhausen, Arch. Pharm. 263, 570 (1925).

4 A. Brossi, in "The Alkaloids", Vol. 34, p. 181-209, Academic Press. Inc., London 1988.

5 M. Kamigauchi, K. Iwasa, N. Takao, T. Ishida, and M. Inoue, Helv. Chim. Acta 70, 1482 (1987).

6 V. Preininger, R.S. Thakur, and F. Santavy, J. Pharm. Sci. 65, 294 (1976); J. Slavik and L. Slavikova, Coll. Czechoslov. Chem. Commun. 44, 2261 (1979); P.T. Minh Hoang, G. Verzar Petri, and E. Fuggerth, Acta Pharm. Hung. 49, 105 (1979); C.A. 91, 112493 y (1979); G. Nonaka, M. Okabe, I. Nishioka, and N. Takao, Yakugaku Zasshi 93, 87 (1973); C.A. 79, 66630r (1973).

7 N. Takao, M. Kamigauchi, and M. Okada, Helv. Chim. Acta 66, 473 (1983); N. Takao, K. Iwasa, M. Kamigauchi, and M. Sugiura, Chem. Pharm. Bull. 24, 2859 (1976).

8 J. Holubec and O. Strouf, "Spectral Data and Physical Constants of Alkaloids", No. 72, Publishing House of the Czechoslovak Academy of Sciences, Prague 1965.

9 A.K. Mills and A.E. Wilder Smith, Helv. Chim. Acta 43, 1915 (1960);

10 W. Leithe, Ber. Disch. Chem. Ges. 63, 2343 (1930); H. Corrodi and E. Hardegger, Helv. Chim. Acta 39, 889 (1956); G.G.Lyle, J. Org. Chem. 25, 1779 (1960); P.W. Jeffs, Experientia 21, 690 (1965); G. Snatzke, J. Hrbek, Jr.L. Hruban, A. Horeau, and F. Santavy, Tetrahedron 26, 5013 (1970).

11 F.R. Stermitz, R.M. Coomes, and D.R. Harris, Tetrahedron Lett. 1968, 3915.

12 K. Iwasa, M. Kamigauchi, N. Takao, M. Cushman, J.K. Chen, W.C. Wong, and A. McKenzie, J. Am. Chem. Soc. 111, 7925 (1989).

[Ph967] 